\title{
INFECTION CONTROL COORDINATOR
}

\section{EMPLOYMENTOPPORTUNITIES}

\section{CENTERS FOR DISEASE CONTROL CENTER FOR INFECTIOUS DISEASES} DIVISION OF BACTERIAL AND MYCOTIC DISEASES DIRECTOR

\section{Applications are invited for the position of Director, Division} of Bacterial and Mycotic Diseases, Center for Infectious Diseases, Centers for Disease Control, Atlanta, Georgia.

The Director is responsible for managing and directing highly complex and comprehensive research programs focused on epidemiologic investigation, surveillance, diagnosis, prevention and control of bacterial and mycotic diseases of national and international importance. He/she serves as a principal resource for the U.S. Public Health Service for public health aspects of bacterial and mycotic diseases.

Qualifications include a doctoral degree (M.D., Ph.D., or

- equivalent), broad knowledge of epidemiologic and laboratory aspects of bacterial diseases and of approaches to the

* prevention and control of bacterial and mycotic diseases, and proven ability to provide administrative and scientific leadership for a multidisciplinary program employing over 170 professional, technical, and administrative personnel, with an annual budget of over $\$ 10$ million.

1 Further information about the position may be obtained from James M. Hughes, M.D., Search Committee Chair,

l Center for Infectious Diseases, Mail Stop C12, Centers for Disease Control, 1600 Clifton Road, Atlanta, GA 30333. Interested candidates should send their curriculum vitae and names of three professional references by September 14, 1990, to Nancy Peterson, Personnel Management Office, Mail Stop D01, Centers for Disease Control, 1600 Clifton Road, Atlanta, GA 30333. Telephone (404)6391521.

CDC is an Equal Opportunity Employer and provides a smoke-free work environment.

\section{SERVICES}

A FAX MACHINE IS AVAILABLE FOR YOUR CONVENIENCE. FAX YOUR CLASSIFIED AD TODAY for placement in the next available issue of INFECTION CONTROL AND HOSPITAL EPIDEMIOLOGY Classified Marketplace (609)853-5991.
RATES: $\$ 18.00$ per line (line $=$ approx. 60characters); $\$ 108.00$ minimum; $\$ 12.00$ extra for confidential box number service. Noncommissionable to agencies.

SEND INSERTION INSTRUCTIONS TO: Classified Marketplace, Infection Control and Hospital Epidemiology, 6900 Grove Road, Thorofare, NJ 08086-9447.

Be sure to include your telephone number. CALL FOR INFORMATION: TOLL-FREE: 800-257-8290, In NJ: 609-848-1000. FAX \# 609-853-5991.
University Hospital, the second largest hospital in Georgia, is seeking a self-motivated individual to direct and manage our Infection Control Department. The candidate will possess excellent interpersonal skills, knowledge of epidemiology and 3 years clinical experience in infection control. Data base management and supervisory experience desirable. CIC certification and/or a Masters Degree in a related area preferred.

Outstanding full-time employee benefits include flexible health and dental, life and disability insurance; on-campus child care; employer-matched tax-deferred retirement program; tuition assistance; and much more.

Interested candidates send resumes to:

UNIVERSITY HOSPITAL

Nurse Recruitment

1350 Walton Way

Augusta, GA 30910-3599

(404) $724-5437$ or $1-800-338-9599$

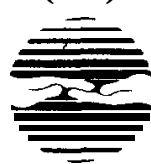

University Hospital

An Affiliate of lniversity Ittalih

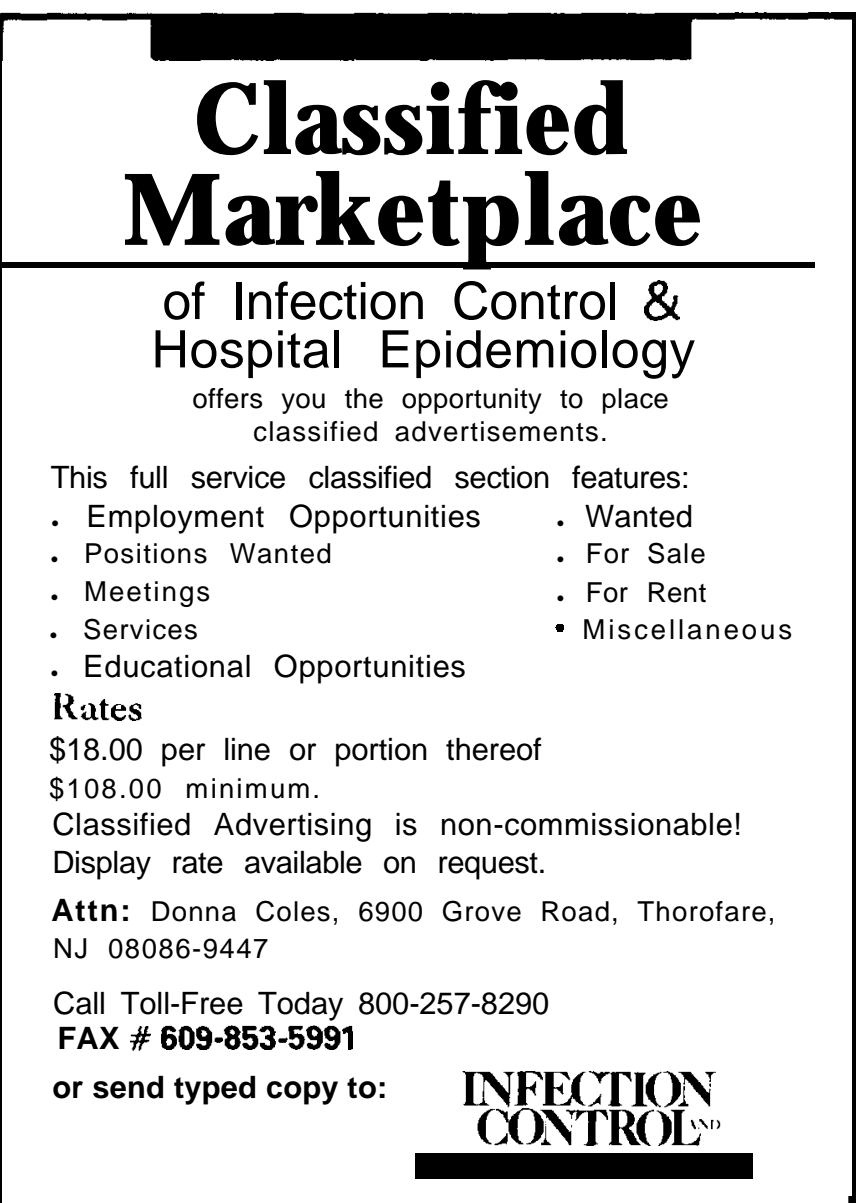




\section{P'RACTICE SEW-DEFENSE}

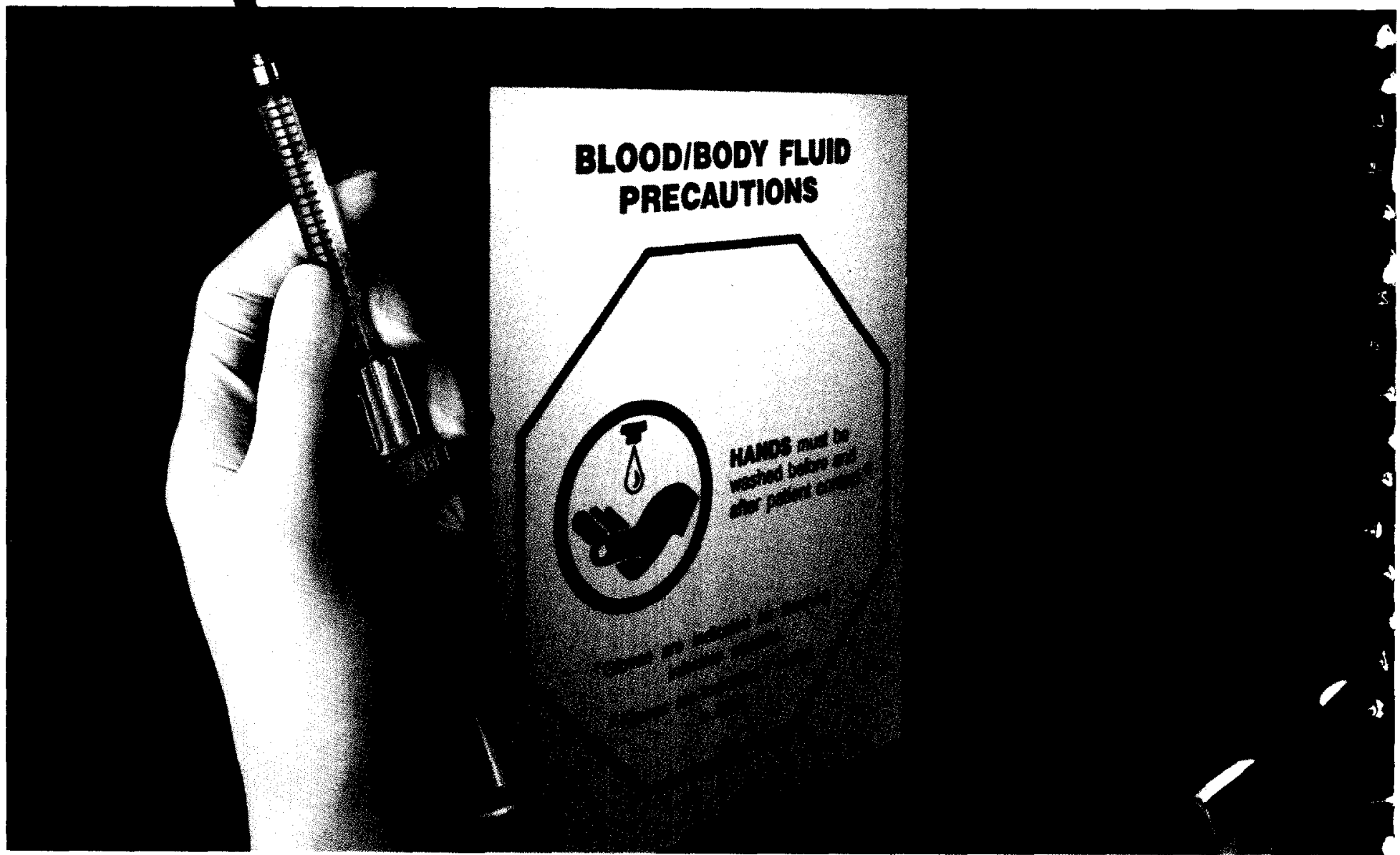

\section{YOUR UFE MAY DEPEND ON IT}

With AIDS cases escalating, on-the-job self-defense has never been more important. Although the risk of seroconversion is low, to date, $60 \%$ of the reported seroconverted healthcare workers had occupational HIV exposure from needlestick injuries.' In addition, an estimated 200 healthcare workers die each year from hepatitis B viruses. ${ }^{2}$

\section{IMPROVED TUBEX” INJECTOR SECURELY GRIPS CARTRIDGE}

Now, the "HANDS-OFF" Injector, TUBEX, has been improved to provide a more secure grip on the cartridge within the Injector. And it's faster and easier than ever to load. The improved TUBEX Injector still offers the same safety advantages: it puts nurses farther from the needle and cartridge than any other injector system. There's no need to touch, shake, manipulate, or angle the needle or cartridge upon disposal.

For the best self-defense injection system against needlestick injuries, use the TUBEX Injector.. .your life may depend on it.

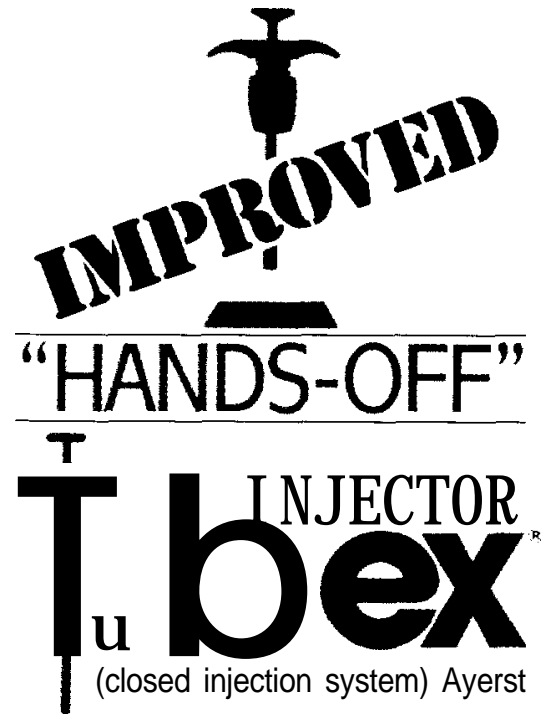

FARTHER FROM THE POINT OF DANGER 